\title{
Comparison of Students' Writing Ability Stimulated in Silent and Motion Series Image Media
}

\author{
Achmad Nurohim, Bambang Yulianto, Suhartono \\ Postgraduate of Universitas Negeri Surabaya, Indonesia \\ SDN Manduro 2, Mojokerto, Indonesia \\ achmad.nurohim15@gmail.com
}

\begin{abstract}
The learning of writing for elementary school students is still dominated by the use of conventional learning media. This results in less attractive learning for students. Consequently, student's learning activities and their learning outcomes are low. These conditions occur in fifth-grade students of SDN Manduro 2, Mojokerto, Indonesia. After the initial writing ability tests, it is known that the students' writing ability is still low. The purpose of this research is to know the comparison between students' writing ability who is stimulated through conventional media namely silent series image media and innovative media namely motion series image media. This research uses experimental method with comparative analysis approach that used test for the data collection technique. The test is performed by following the rotation design, a learning design involving two groups of samples with two rounds of treatment performed in turns and exchange. The results of the research showed a significant difference due to the different stimuli of the students' imagination from two different types of image series media. Based on the results of this research showed that the students' writing ability stimulated the motion series image media better than the silent series image media.
\end{abstract}

Keywords-Writing ability; Silent series image media; Motion series image media.

\section{INTRODUCTION}

One of the absolute abilities that must be owned and developed by elementary school students is language ability. Perceiving good language abilities will support the capabilities of other aspects. If the students have the language ability, then they will more easily receive new information or knowledge. Therefore, language abilities in students should be nurtured early because the language ability is not obtained instantly but through a long process. The language ability is not necessarily obtained simultaneously perfect, but gradually grew from childhood to adulthood [1]

In accordance to language ability, there are four interconnected abilities namely listening, speaking, reading, and writing. In Tarigan's terminology, the four language abilities are called language skills [2]. The four language abilities that have something to do with this research is only writing ability. Learning of writing for elementary school students is still dominated by the use of conventional media, especially silent image series media. This results in unattractive and unpleasant learning for students. So the student learning activity becomes low and their writing result is also low.

Baumann \& Duffy [3] suggest that the results of some research also show that a teacher who is also a researcher of learning activities not only provides a tool to assist in studentcentered pedagogic guidance but also as a tool for teachers to address problems in the classroom and school.

Research related to child language development including writing ability has been done by many experts. In general, the research of language development of children is done longitudinally, so that eventually resulted in the periodization of language development of children, although sometimes different from one another. Nonetheless, the linguistic substance stages are relatively similar [4]

Furthermore, Yulianto [5] adds that language learning should be based on the principle of language learning in general. The principle of Indonesian language learning should emphasize language learning activities, not learning about the language itself. Therefore, the emphasis on language learning should take precedence over learning Indonesian language skills. Thus the children not only learn the theory of language but also learn the practice of language directly which is certainly based on the curriculum applicable and established by the school.

The curriculum has an important role as a blueprint for a teacher and student in achieving learning goals [6]. With regard to the current curriculum, Suhartono [7] states that the new curriculum In Indonesia, it's called the 2013 curriculum, provides much new knowledge and insight for an Indonesian teacher. One of them is text-based language learning. In contrast to previous curriculum-based language skills, with text-based learning, the learning paradigm will be oriented to real products, namely text. And every student is required to have the competence to construct the text.

Language abilities in the elementary school curriculum include four aspects: a) listening ability, b) speaking ability, c) reading ability, and d) writing ability. Tarigan [2] states that the four abilities are basically a unity that cannot be separated from one another which is then referred to as a single chess. 
Among them is reading, if a student is fond and has a high interest in reading, then he will have a lot of vocabulary and can be developed in the practice of writing. Especially reading the story, Okumu and Ceylan [8] revealed that reading the story can increase his desire to read more and appreciate the literature. With the vocabulary possessed from the reading will make it easier for students to develop their writing ability.

Stories can also be delivered to students via digital media. Van Galen [9] also added that digital-based stories can dilute students' tension as well as a teacher in conveying a story. In other words, digital-based media can be used to reduce deadlock thinking for a teacher in the interaction of learning with students or social interaction in community life.

Indonesia is listed as one of the countries that succeeded in reducing illiteracy. The UN noted that the literacy rate in Indonesia reached $92.8 \%$ for the adult group, and $98.8 \%$ in the adolescent category. This achievement shows that Indonesia's literacy crisis has passed. Nevertheless, challenges remain, and one is the lack of interest in reading. In addition, the availability of books throughout Indonesia is inadequate. The government also faces low reading motivation among students, teachers and the wider community [10]

Ghazanfari [11] states that the ultimate goal of the reading activity is to gain an understanding of the text content. Without that understanding, the reader has not been said to be successful in the task of reading it. In addition, understanding the contents of the text is an important prerequisite for recalling reading material that has been read. By reading we not only acquire new knowledge but also new ideas that can be applied after reading activity is over, that is writing activity.

Writing ability is a productive ability that requires the ability and creativity of thinking. This ability should be instilled in elementary school students by providing fun learning using innovative media such as moving image media.

Rindermann [12] asserted that writing is an application of cognitive ability: intelligence (ability to think), knowledge (words and concepts) and the use of intelligent knowledge. Olive [13] also revealed that writing is a cognitive activity involving a large number of cognitive components. Porter and Hernacki [14] add that writing is an entire brain activity involving the right hemisphere (emovingal) and the left hemisphere (logic). Both have contributed to the success of writing. Even so, the role of the right brain is more dominant because, in the right brain new ideas, passions and emotions arise that is ammunition in writing.

In essence, the definition of writing ability can be formed through the teacher based on his or her experience as a teacher, can also be formed using a pedagogical approach to the teaching of writing adopted by each teacher [15]. Furthermore, Calkin [16] also states that writing is a conscious effort without coercion and usually without deadlines. So, writing is a conscious effort done by someone without the coercion of others and without a certain time limit, so that the aesthetic element can appear naturally, so students will love writing activities by itself. Similarly, for teachers, it is a demand to provide feedback that can help students [17].

In this research, students' writing ability is stimulated through silent series images media and motion series images media. The silent series image media is a two-dimensional visual media that is static and contains a sequence of interconnected images and states a sequential event. While the motion series images media in this research is an animated visual media that does not contain sound elements and can move which contains a series of still images that are interconnected and declare coherent and systematic events. It can be said also that the motion series images media is a form of animation and an innovation of silent series image media. This is done because innovation is one of the important manifestations in the activities of educational change [18]

Some research on teaching using image media shows how complex the concept of the subject is related to the development of new technology [19]. Therefore, the image media is one of the media that is very familiar in every learning process.

From a wide variety of visual media, moving images include part of a media type that has a very urgent visual role in the learning process. Through visual or movement of an image media students usually, more easily accept and understand a concept of learning well compared with static images. Moving or animated images include the type of motion-visual media, which is a medium that has a moving object image, but does not make a sound, like a moving mute film, so the image appears more alive, interesting and fun for students.

To display this motion series images media requires hardware in the form of a computer and LCD projector. It also uses the software in the form of power point applications. Through the combination of hardware and software then this motion series images media can be displayed optimally so that students can see and pay attention to it clearly.

According to Mayer and Moreno [20] the animation has three main features: (1) the animated image is a depiction; (b) motion-animation describes a movement; (c) animations composed of objects created by drawing or other simulation methods. During this animation used in learning media for two reasons, namely to attract students' attention and strengthen student motivation.

With regard to the use of silent series image media and motion series image media, Munir [21] stated that the value of graphic media, such as the image media series lies in its ability to attract attention and interest in conveying certain types of information appropriately to the students. The theory is evidenced through the results of research conducted by Sarica and Usluel [13] Hacettepe University, Turkey which shows that the use of digital media is quite effective to improve students' writing ability. Motion series image media is one of those types of digital media. 
Lowe [22] says that novice learners such as elementary school students who do not have early knowledge will tend to pay more attention to perceptually interesting animation changes compared to changes that are important in understanding the material. According to the theory of mental animation [23], students who are shown the frames in the animation still need to mentally animation able how the system works. Such mental animation leads to better information processing and advancement. Students will interact directly with animation actively, therefore will provide support to students to build a dynamic mental model of the process that occurs.

Mayer [20] says, learning using multimedia requires active learning of students on instructional materials; just showing animation alone may not provide meaningful help for students to learn, but the dynamic aspect of the various elements in controlled animation will require more cognitive processing as they attempt to perceive and comprehend animated content.

While the animation is more advantageous than using static media, studies that compare the use of animation and static illustrations in learning show mixed results, some of which show positive results, but some show negative results. A meta-analysis research by Ke, Lin, Ching, Dwyer [24] on learning animation, comparing the results of research in animation use for learning, showed that on average, groups using animated media experienced an increase in multi-level learning by $62 \%$, while the group using the static media increased by $50 \%$ only.

Digital-based animation media, as Weigle [25] says technology influences writing in various ways. For example, the social aspect of writing becomes more relevant because perhaps the author knows that their text will be published online. Or it could be in a networking class, a good piece of writing will be obtained through a community where there are writers who reflect on their new ideas.

This research was conducted with the aim of identifying differences of the elementary school students writing ability for two proportional sample groups that simultaneously carry out writing lessons with two different types of series image media, silent and motion series image media. In addition, the results of this research will serve as a recommendation material to teachers in determining the use of series image media for the learning of writing on elementary school students.

The purpose of the above research can be realized by referring to the formulation of the problem to be searched answer, that is how the difference average ability to write students of class $\mathrm{V}$, either group V-a or group V-b equally carry out writing learning by stimulated through silent and motion series image media.

\section{METHOD}

\section{A. Research Design}

This research uses the experimental method with comparative analysis approach. The experimental method is used to determine the students' writing ability that is stimulated through the silent series images media and the motion series image media. While the comparative analysis approach is used to find out the comparison of students' writing ability which is stimulated through silent series image media and motion series image media.

Comparative analysis is done by comparing the writing ability of two groups of samples that are stimulated through silent series image media and motion series image media. Through this comparative analysis can be seen the comparison of the ability to write two groups of samples after stimulated through two different types of image series media. These methods and approaches were chosen because they were in accordance with the research objectives to be achieved that was to identify the students' writing ability of class $\mathrm{V}$ of elementary school that was stimulated through silent series image media and motion series image media.

This research is purely experimental by using a rotational design, a design that can be used with intact class groups, rotating or swapping groups at specific intervals during an experiment. A prominent feature of this design is that all research subjects received all experimental treatment at a time during the experiment. So all the sample groups in this research received the same treatment, that is both get the writing lesson using the silent image series media and motion series image media.

The rotation design in this research is described as follows:

\begin{tabular}{|llc|}
\hline \multicolumn{1}{c}{ Treatment } & \multicolumn{2}{c|}{ Two sample groups } \\
& \multicolumn{1}{c}{$\mathrm{V}-\mathrm{a}$} & $\mathrm{V}-\mathrm{b}$ \\
\cline { 2 - 3 } First & $\mathrm{X}_{1}$ & $\mathrm{Y}_{1}$ \\
Second & $\mathrm{Y}_{2}$ & $\mathrm{X}_{2}$ \\
\hline
\end{tabular}

Figure 1: Rotation Design

$\begin{array}{cl}\text { Note: } \mathrm{V}-\mathrm{a} & : \text { Group sample of V-a } \\ \mathrm{V}-\mathrm{b} & : \text { Group sample of V-b } \\ \mathrm{X} & : \text { Stimulation of silent series image media. } \\ \mathrm{Y} & \text { : Stimulation of motion series image media. } \\ 1 & \text { : Theme of farm } \\ 2 & : \text { Theme of game }\end{array}$

\section{B. Population and Sample}

The population used in this research is all of the fifth-grade students of SDN Manduro 2, Mojokerto, Indonesia as many as 55 students with two research groups. Sampling in this research using proportional sampling technique, sample determination technique by putting forward balance aspect, balance in quantity also in ability. In this research, the 
determination of the sample was obtained by following the formula Isaac and Michael with a 5\% error rate.

By following the formula then obtained the total of samples of 48 students consisting of two research groups. The two research groups are then tested the ability of the initial writing is done simultaneously and collectively in one room, which then the test results are proportionally distributed into groups of research samples. The sample consists of two groups, namely group $\mathrm{V}$-a and group $\mathrm{V}-\mathrm{b}$.

\section{The technique of Data Collection}

There are two main things that affect the quality of research data, namely the quality of research instruments and the quality of data collection. Data collection techniques are the most important step in the research. This is because the main purpose of a research is to obtain data. Without knowing the techniques of data collection, the researchers will not get data that meets the established data standards.

The data collection techniques in this research just use a relevant method to be used as data collection tool, it is test methods.

\section{The technique of Data Analysis}

Data analysis is a very important step in the research after all the data collected complete, the data must be analyzed. The data obtained from the sample through the selected instrument will be used to answer the research problem formulation and simultaneously test the proposed hypothesis.

Therefore the data needs to be processed and analyzed with certain techniques in order to have meaning for solving research problems. Data analysis in this research using parametric statistical analysis technique. This analysis technique is used to test population parameters through statistics, or to test population size through sample data which is then generalized to the population.

\section{RESULTS AND DISCUSSION}

\section{A. Student' Writing Ability Stimulated Through Silent Series Image Media}

The experimental writing ability that is stimulated through this silent series image medium is carried out on two balanced sample groups using different learning themes based on the rotation design. The $\mathrm{V}$-a group carries out the stimulating learning through the silent series image media with the theme of a farm, whereas the V-b group executes the stimulating learning through silent series image media with game themes.

The results of experimental writing ability that is stimulated through silent series image media with these different themes show that learning activities tend to be boring, learning passion and weak writing student creativity. This is evidenced by the acquisition of student writing scores as follows.
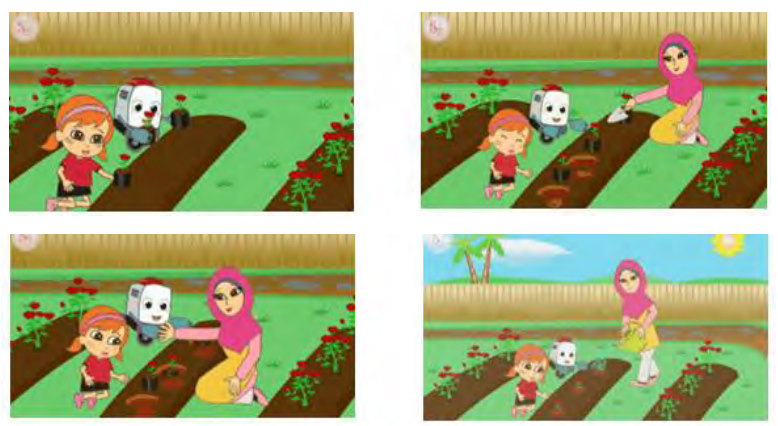

Figure 2: The example of silent series image media

The average acquisition value of students' writing ability is stimulated through silent series image media with the theme of a farm $\left(\mathrm{X}_{1}\right)$ of 63.33 , and the average value of students' writing ability is stimulated through silent series images with the game theme $\left(\mathrm{X}_{2}\right)$ of 68.33 . So the comparison of the average gain value of the two silent series image media with the different themes there is a small increase of $7 \%$.

Based on the average acquisition of these values, although using the same media and different themes but the average acquisition value of students' writing ability tends to stagnate.

This is in line with the results of research conducted by Dina Utami [26] in her journal entitled "Animation in Learning", in Science Learning Magazine No. 1 Volume 7 Yogyakarta State University. The results show that the use of static media is not better than the animation media, on average only $36 \%$ under the animation group with an average of $64 \%$.

TABLE I.

THE RESULT OF COMPARISON OF THE ELEMENTARY SCHOOL STUDENTS' WRITING ABILITY STIMULATED THROUGH SILENT SERIES IMAGE MEDIA

\begin{tabular}{|c|c|c|}
\hline \multirow{3}{*}{ Parameter } & \multicolumn{2}{|c|}{ Writing Student Ability } \\
\hline & Group V-a & Group V-b \\
\hline & $X_{1}$ & $X_{2}$ \\
\hline Sample (n) & 24 & 24 \\
\hline Score & 1520 & 1640 \\
\hline Score Maximum [Max] & 80.00 & 80.00 \\
\hline Score Minimum [Min] & 50.00 & 55.00 \\
\hline Rentang [R] & 30.00 & 25.00 \\
\hline Average $[\overline{\mathrm{x}}]$ & 63.33 & 68.33 \\
\hline
\end{tabular}

To clarify the above data, histogram presented as follows:

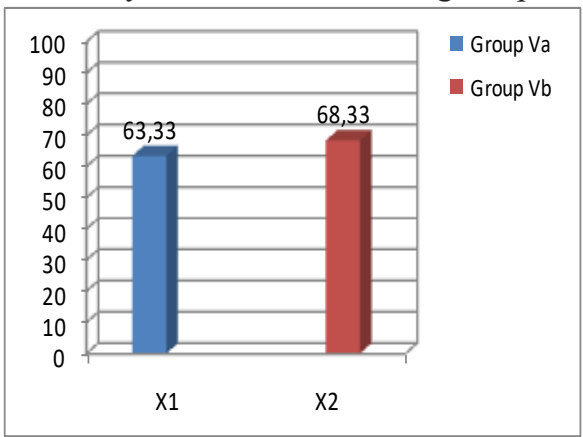

Figure 3: Histogram of comparison of values $X_{1}$ and $X_{2}$ 


\section{B. Student' Writing Ability Stimulated Through Motion series Image Media}

The experimentation of writing abilities stimulated through the motion series image media was carried out on two balanced sample groups using different learning themes that were carried out with the rotation design. The $\mathrm{V}$-a group carries out the stimulating learning through the motion series image media with the theme of a farm $\left(\mathrm{Y}_{1}\right)$, while the group $\mathrm{V}-\mathrm{b}$ conducts the learning stimulated through the motion series image media with the game theme $\left(\mathrm{Y}_{2}\right)$.

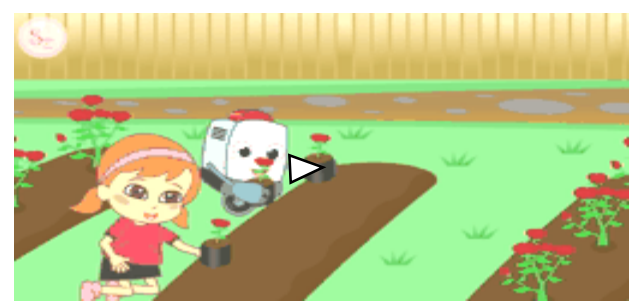

Figure 4: The example of motion series image media

This motion series image media is an image media that is not static, can move and is the result of innovation from silent series image media. The results of experimental writing abilities that are stimulated through motion series image media with these different themes show that learning activities tend to increase, the passion of learning and creativity of high student writing. This is evidenced by the comparative value of students' writing ability as follows.

The average acquisition value of students' writing ability is stimulated through the motion series image media with the theme of a farm $\left(\mathrm{Y}_{1}\right)$ of 75.63 , and the average value of writing ability is stimulated through the motion series image media with the game theme $\left(\mathrm{Y}_{2}\right)$ of 77.71 . The average value of writing ability that is stimulated through motion series image media while using different themes reaches a value above the minimum mastery criteria and tends to increase by $3 \%$. And the average of both values is 76.67 .

This is supported by the results of research conducted by Ke, F., Lin, H., Ching, Y., Dwyer, F. [24] in his journal entitled "Effects of Animation on Multi-Level Learning Outcomes for Learners with Different Characteristics: A Meta-Analytic Assessment and Interpretation". Journal of Visual Literacy, Spring 2006 volume 26, number 1, pp.15-40, which suggests that, when compared to static media, the animation is much more likely to increase students' motivation and learning outcomes. $80 \%$ of students who do the learning process using animated picture media show higher passion and passion than students who use static image media.
TABLE II.

THE RESULT OF COMPARISON OF THE ELEMENTARY SCHOOL STUDENTS' WRITING ABILITY STIMULATED THROUGH MOTION SERIES IMAGE MEDIA

\begin{tabular}{|c|c|c|}
\hline \multirow{3}{*}{ Parameter } & \multicolumn{2}{|c|}{ Writing Student Ability } \\
\hline & Group V-a & Group V-b \\
\hline & $Y_{2}$ & $Y_{1}$ \\
\hline Sample (n) & 24 & 24 \\
\hline Score & 1865 & 1815 \\
\hline Score Maximum [Max] & 90.00 & 90.00 \\
\hline Score Minimum [Min] & 65.00 & 70.00 \\
\hline Rentang [R] & 25.00 & 20.00 \\
\hline Average $[\overline{\mathrm{x}}]$ & 77.71 & 75.63 \\
\hline
\end{tabular}

To clarify the above data, histogram presented as follows:

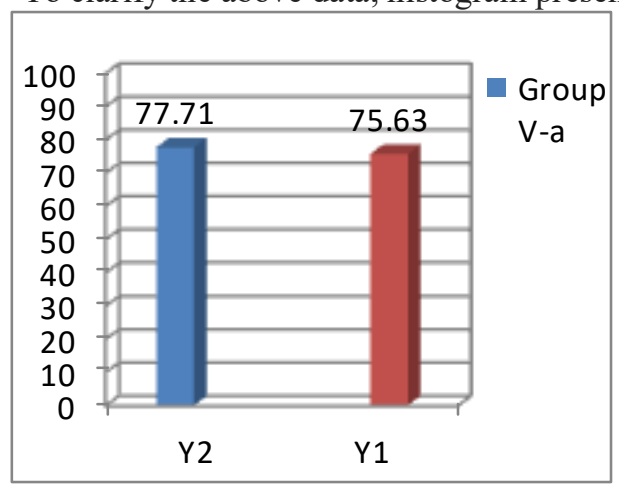

Figure 5: Histogram of comparison of values $\mathrm{Y}_{2}$ and $\mathrm{Y}_{1}$

\section{Student' Writing Ability Stimulated Through Silent and Motion series Image Media}

After analyzing the results of the two experiments mentioned above, then will be done the comparative analysis of the acquisition value of writing ability that is stimulated through two types of different series image media. Based on the results of experimental analysis of students' writing ability which is stimulated through silent series image media obtained average value of 68.33 , while the result of experimental analysis of students' writing skill which is stimulated through motion series image media obtained an average value of 76.67. So it can be seen that the comparison of students' writing ability that is stimulated through the motion series image media more increased by $15 \%$ of the silent series image media.

By comparison the average value of the results of both experiments shows a significant difference which means that the writing ability of students who are stimulated through the motion series image media better than the silent series image media.

This is in line with the results of the research by Dina Agustina (without years) entitled "Comparison of Student Learning Results Using Motion and Silent Image", shows that the average posttest of motion images group is 69.13, greater than the group learning outcomes silent images group with a posttest average of 53.3. The positive response to the use of motion images reaches $97 \%$ and the positive response to the use of silent images is only $84 \%$. 


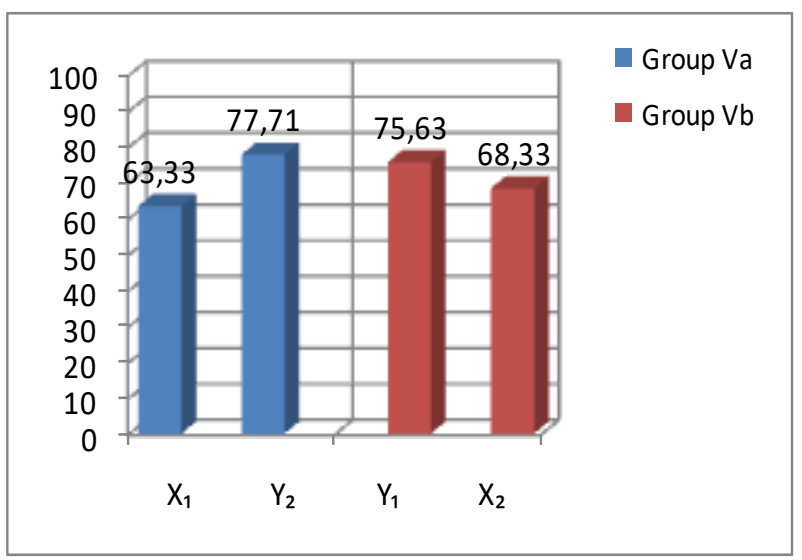

Figure 6: Histogram of comparison of the elementary school students' writing ability

D. Comparison of Student' Writing Ability Average Stimulated Through Silent and Motion series Image Media

The results of the above experiments can be narrowed down by analyzing the average comparisons of students' writing comprehension scores through the silent series image $(\mathrm{X})$ and the motion series image media $(\mathrm{Y})$ of the two sample groups, as shown in the following table:

TABLE III

THE RESULT OF COMPARISON OF AVERAGE THE ELEMENTARY SCHOOL STUDENTS' WRITING ABILITY StimUlated Through Silent Series IMAGe Media AND MOTION SERIES IMAGE MEDIA

\begin{tabular}{|c|c|c|}
\hline \multirow[b]{2}{*}{ Parameter } & \multicolumn{2}{|c|}{ Writing Student Ability } \\
\hline & $\begin{array}{c}\text { Average } \\
\text { value of } X\end{array}$ & $\begin{array}{c}\text { Average } \\
\text { value of Y }\end{array}$ \\
\hline Sample (n) & 24 & 24 \\
\hline Score & 1580 & 1840 \\
\hline Score Maximum [Max] & 80.00 & 87.50 \\
\hline Score Minimum [Min] & 55.00 & 67.50 \\
\hline Rentang [R] & 25.00 & 20.00 \\
\hline Average $[\overline{\mathrm{x}}]$ & 65.83 & 76.67 \\
\hline
\end{tabular}

To clarify the above data histogram presented as follows:

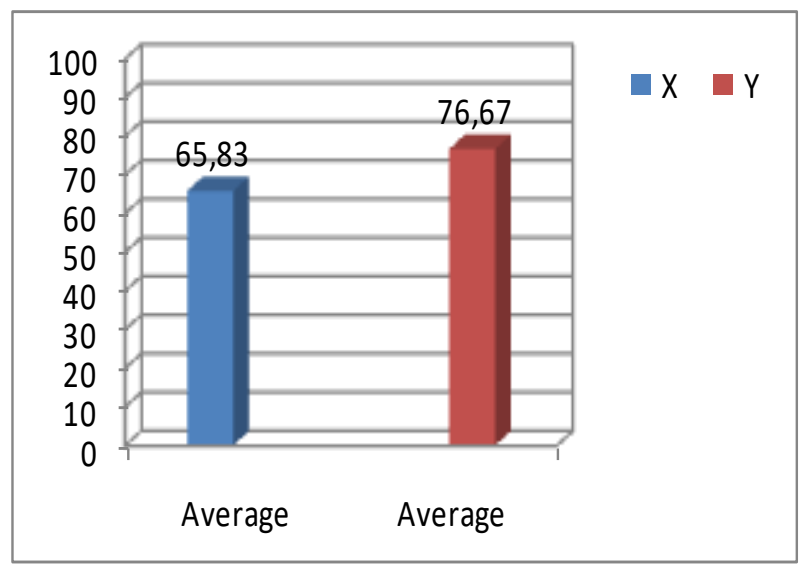

Figure 7: Histogram of comparison of values $\mathrm{X}$ dan $\mathrm{Y}$

\section{CONCLUSION}

Based on the results of data analysis and hypothesis testing, it can be concluded as follows:

1. There is a significant difference between the students' writing ability that is stimulated through the silent series image media and the motion series image media. This can be proved after hypothesis testing which mentions the existence of significant differences in the ability of students who are stimulated through the silent series images and motion series image media.

2. The students' writing ability who are stimulated through the motion series image media better than the silent series image media. This can be proven after hypothesis testing which states that the students' writing ability that is stimulated through the motion series image media better than the silent series image media.

3. There is a significant correlation between the students' writing ability with the stimulus of motion series images and silent series images. This can be proven after hypothesis testing which shows that the writing ability of students to be better after the learning using stimulus media series moving images.

\section{SUGGESTION}

Based on the conclusions of the research authors suggest:

1. We recommend that teachers consider first before selecting and determining the learning media that will be used to improve students' writing ability.

2. We recommend that teachers also consider the use of media between silent series images and motion series image media in improving students' writing ability.

3. We recommend that teachers use motion series images media that are considered more innovative, interesting and fun in improving students' writing ability.

4. Teachers can create a more innovative, interesting and fun learning media so that students are more motivated to improve their writing ability.

\section{REFERENCES}

[1] B. Yulianto, "Kurikulum Bahasa Indonesia: Problematika di Lapangan," Diksi, vol. 14, no. 1, 2007.

[2] H. G. Tarigan, "Menulis: Sebagai Suatu Keterampilan Berbahasa Pada Anak Usia Dini Melalui Penggunaan Media Audio Visual Pada Kelompok B1 TK PlusMa'Arif Balai-balai Padang Panjang Barat," J. Guru, no. 2, 2008.

[3] L. A. Taylor, "How teachers become teacher researchers: Narrative as a tool for teacher identity construction," Teach. Teach. Educ., vol. 61, pp. 16-25, 2017

[4] B. Yulianto, Perkembangan Struktur Kata dan Suku Kata Pada Tahap Kalimat Kata Tunggal Hingga Kalimat Sederhana dan Kompleks. Surabaya: Prosiding Seminar Nasional Paramasastra 4, 2016.

[5] B. Yulianto, "Mengembangkan Menulis Teknis." Unesa University Press, 
Surabaya, 2008.

[6] B. Yulianto, A. Ahmadi, and P. V Asteria, "Development of short Indonesian lesson plan to improve teacher performance," in IOP Conference Series: Materials Science and Engineering, 2018, vol. 296, no. 1, p. 12001.

[7] Suhartono, Kesenjangan Desain Pembelajaran Teks Sastra Dalam Praktik Pembelajaran Berbasis Teks: Studi Pada Aktivitas Peserta Didik. Surabaya: Prosiding Seminar Nasional Permasastra 4, 2016.

[8] N. O. Ceylan, "Using short stories in reading skills class," ProcediaSocial Behav. Sci., vol. 232, pp. 311-315, 2016.

[9] J. A. Van Galen, "Agency, shame, and identity: Digital stories of teaching," Teach. Teach. Educ., vol. 61, pp. 84-93, 2017.

[10]K. Laksono and P. Retnaningdyah, "Literacy Infrastructure, Access to Books, and the Implementation of the School Literacy Movement in Primary Schools in Indonesia," in IOP Conference Series: Materials Science and Engineering, 2018, vol. 296, no. 1, p. 12045.

[11]M. Ghazanfari, M. Ziaee, and E. Sharifianfar, "The impact of illustrations on recall of short stories," Procedia-Social Behav. Sci., vol. 98, pp. 572$579,2014$.

[12]H. Rindermann, C. D. Michou, and J. Thompson, "Children's writing ability: Effects of parent's education, mental speed and intelligence," Learn. Individ. Differ., vol. 21, no. 5, pp. 562-568, 2011.

[13]H. Ç. Sarıca and Y. K. Usluel, "The effect of digital storytelling on visual memory and writing skills,” Comput. Educ., vol. 94, pp. 298-309, 2016.

[14]B. DePorter, M. Hernacki, and A. Abdurrahman, Quantum learning: membiasakan belajar nyaman dan menyenangkan. Penerbit Kaifa, 1999.

[15]J. Yi, "Defining Writing Ability for Classroom Writing Assessment in High Schools.," J. Pan-Pacific Assoc. Appl. Linguist., vol. 13, no. 1, pp. 53-69, 2009.
[16] A. B. Calkin, "Writing on writing," Int. J. Educ. Res., vol. 87, pp. 127$137,2018$.

[17]J. F. K. Lee, "Enriching short stories through processes-A functional approach," System, vol. 58, pp. 112-126, 2016.

[18]P. Made, Wawasan Pendidikan. Surabaya: Unesa University Press, 2016.

[19]H. Örtegren, "The scope of digital image media in art education," Comput. Educ., vol. 59, no. 2, pp. 793-805, 2012.

[20]R. E. Mayer and R. Moreno, "Animation as an aid to multimedia learning," Educ. Psychol. Rev., vol. 14, no. 1, pp. 87-99, 2002.

[21]M. I. T. Munir and D. Prof, "Multimedia Konsep dan Aplikasi dalam Pendidikan.” Bandung: Alfabeta, 2012.

[22]R. K. Lowe, "Animation and learning: selective processing of information in dynamic graphics," Learn. Instr., vol. 13, no. 2, pp. 157176, 2003.

[23] M. Hegarty, S. Kriz, and C. Cate, "The roles of mental animations and external animations in understanding mechanical systems," Cogn. Instr., vol. 21, no. 4, pp. 209-249, 2003.

[24]F. Ke, H. Lin Kun Shan, Y.-H. Ching, and F. Dwyer, "Effects of animation on multi-level learning outcomes for learners with different characteristics: a meta-analytic assessment and interpretation," J. Vis. Lit., vol. 26, no. 1, pp. 15-40, 2006.

[25]L. Cuesta and S. Rincón, "Short story student-writers: active roles in writingthrough the use of e-portfolio dossier," Colomb. Appl. Linguist. J., vol. 12, no. 1, pp. 99-114, 2010.

[26]D. Utami, “Animation in Learning," Science Learning Magazine No. 1, vol. 7, Yogyakarta, 2011. 